\title{
At the Meetin' Tree: Reading, Storytelling, and Transculturation in Daniel Black's They Tell Me of a Home
}

Pekka Kilpeläinen

\section{(2) OpenEdition \\ Journals}

Electronic version

URL: https://journals.openedition.org/ejas/11607

DOI: $10.4000 /$ ejas. 11607

ISSN: 1991-9336

Publisher

European Association for American Studies

Electronic reference

Pekka Kilpeläinen, "At the Meetin' Tree: Reading, Storytelling, and Transculturation in Daniel Black's They Tell Me of a Home", European journal of American studies [Online], 11-2 | 2016, document 10, Online since 11 August 2016, connection on 08 July 2021. URL: http://journals.openedition.org/ejas/11607 ; DOI: https://doi.org/10.4000/ejas.11607

This text was automatically generated on 8 July 2021.

Creative Commons License 


\section{At the Meetin' Tree: Reading, Storytelling, and Transculturation in Daniel Black's They Tell Me of a Home}

Pekka Kilpeläinen

\section{Introduction: Mobility and Transculturation}

1 African American experience is often associated with a sense of collective dislocation that can be traced back to the history of transatlantic slave trade. As Paul Gilroy points out, "in the history of the black Atlantic...movement, relocation, displacement, and restlessness are the norms rather than the exceptions" (133). In this context, it is common for mobility to be conceptualized as a way of responding to the sense of dislocation and homelessness. It is also a central issue in They Tell Me of a Home (2005), the debut novel by the African American writer Daniel Black. Mobility in Black's novel may be read in terms of this impulse to relocate and move or, in Gilroy's words, as "the tension between roots and routes" (133). The main conflicts in the novel revolve around the problematic homecoming of the protagonist and the personal and ideological issues that his homecoming raises. Tommy Lee Tyson, or T.L., as he is usually called, returns to his home in the black community of Swamp Creek in rural Arkansas after a ten-year absence, during which he has received a Ph.D. in Black Studies in New York. He arrives with a rather self-assured, elitist view of his home community and its values, but his attitude eventually changes, in significant ways, as his reencounter with his cultural origins forces him to reevaluate the issues that made him leave.

2 T.L.'s mobility may be understood in terms of the tension between the diasporic displacement that Gilroy discusses and the socially transformative agenda suggested by Weert Canzler, Vincent Kaufmann, and Sven Kesselring, who endorse "the idea of using 
spatial movement as a 'vehicle' or an instrument for the transformation of social situations and in the end to realize certain projects and plans" (3-4). T.L. left his rural home in order to pursue academic goals as a result of his profound disagreement with the conservative values of his Southern community. His home was always a place where he experienced the immediate effects of those values in an intensely personal and intimate way that made him feel alienated and excluded. In other words, home has always signified displacement and dislocation to him, instead of providing a safe haven and a sense of belonging. His reasons for returning home are rooted in the same conflicts and endeavors; that is, he comes back home because of his longing to reconnect with his cultural roots and, in a somewhat idealistic and elitist sense, to address and solve the problems he has perceived in his community.

3 In this article, I will discuss the ways in which T.L.'s homecoming interrupts the conservative, patriarchal order of Swamp Creek and, significantly, also leads him to reassess his problematic, arguably elitist relation to his cultural heritage. It is crucial to notice that the novel does not, in the end, endorse a colonization of the values of the Southern black community of Swamp Creek by the values of academic intelligentsia, although T.L.'s thinking initially seems to run along these lines. Rather, the outcome of this clash of cultures and ideologies implies the establishment of new, meaningful cultural exchange between T.L. and his community, as he arrives at an enhanced appreciation of the communal practice of oral storytelling in Swamp Creek and manages to initiate a transformation in the attitudes of the community toward education. This reading of They Tell Me of a Home seeks to explicate the ways in which the novel represents African American oral tradition and literature and their ideological underpinnings. My approach to the novel uses the concepts of transculturation, mobility, and cultural trauma as theoretical tools. My intent is to encourage critical discussion of a novel that tackles several important questions, but has, to my knowledge, hardly received any serious critical attention. Where appropriate, I will also refer to Black's fourth novel, Twelve Gates to the City (2011), a sequel to They Tell Me of a Home, since many of the same issues are in focus in both novels.

4 The clash of academic and local values establishes intriguing premises for a transcultural reading, primarily on two different levels. Firstly, on the ideological level, T.L. re-encounters the oppressive and reactionary modes of thinking-such as sexism, heteronormativity, and incredulity towards education-that played a significant role in his decision to leave Swamp Creek and pursue an academic career. It is important to stress, however, that these phenomena are by no means exclusive to the rural Southern black community. Instead, the patriarchal values of Swamp Creek should be read as resulting from attempts to conform to the norms of the prevailing ideological climate in the Southern United States. Secondly, on the aesthetic level, the conflicting sets of values are mainly connected to their respective modes of cultural representation, that is, oral storytelling and literary expression. The ways in which these cultural encounters are negotiated produce glimpses of transculturality in the sense of working towards an enhanced understanding of both of these cultural modes and the possible outcomes of their interaction.

5 The concept of transculturation provides tools for analyzing and understanding the cultural clash between T.L. and his community. My concept of transculturation is based on Mary Louise Pratt's definition of the contact zone as 
the space of colonial encounters, the space in which peoples geographically and historically separated come into contact with each other and establish ongoing relations, usually involving conditions of coercion, radical inequality, and intractable conflict. (6)

6 It must be noted that in the case of T.L.'s homecoming, we are not dealing with a colonial context but, rather, an intracultural one involving people sharing the same geographical, historical, and cultural heritage. It is important to understand, however, that in some ways, T.L.'s ten-year absence and return to his birthplace give rise to similar phenomena to those described by Pratt, albeit on a different scale. This is because T.L. has always been an outsider in Swamp Creek, alienated from the ideological and cultural conventions of the small black rural community. Although he has lived most of his life in this social context, he has never been able to adhere to its conservative values. What is at stake here may be read in accordance with Frank Schulze-Engler's account of transculturation as "the productive communicative processes by which individuals and social groups make sense of culture in the contemporary world" (93). This is exactly what occurs in They Tell Me of a Home, as T.L. re-encounters the conservative, patriarchal culture of his home and community and attempts to redefine his relation to and position in it, eventually leading to new visions of reconciliation.

7 Read against the backdrop of African American history, the conflicts in the novel may be understood in terms of what Gilroy has famously termed "the memory of slavery" (39). As Ron Eyerman points out, "the notion of 'African American' is...a historically formed collective identity" and the memory of slavery has been central in this process of identity formation, "not so much as individual experience, but as collective memory" (76). The memory of slavery is a cultural trauma that continues to have significant effects on the present and requires ongoing negotiation. According to Eyerman, "cultural trauma refers to a dramatic loss of identity and meaning, a tear in the social fabric, affecting a group of people that has achieved some degree of cohesion" (61). Rooted in the history of involuntary mobility, forced servitude, and all the related phenomena and consequences, the traumatic memory of slavery provides a key to reading the issues grappled with in They Tell Me of a Home. In their conflicting ways, both the agrarian community of Swamp Creek and T.L. attempt to deal with the memory of slavery and its cultural trauma, and it is T.L.'s homecoming that forces these two ways of remembering into cultural contact with each other. It is crucial to notice, however, that the memory of slavery is not exclusively about the disastrous effects of oppression, but should be thought of, as Gilroy does, "as a living intellectual resource in [black] expressive political culture" (39). This is exemplified in the novel by both the oral storytelling tradition of Swamp Creek and the African American literary tradition endorsed by T.L. These modes of African American cultural production may be regarded as both creative and critical manifestations and negotiations of cultural trauma. Similarly, mobility is understood both as a manifestation of and as a way of negotiating the loss of roots through enslavement.

\section{Homecoming and Ideological Conflict}

8 The central conflicts in They Tell Me of a Home are triggered by the act of homecoming, which brings the concept of home and its complex history in the African American context into focus. The African American experience of home tends to diverge from the 
conventional, idealized conception of home as a place of shelter, stability, security, and comfort. As Biddy Martin and Chandra Talpade Mohanty contend in their article "Feminist Politics: What's Home Got to Do with It?"

"[b]eing home" refers to the place where one lives within familiar, safe, protected boundaries; "not being home" is a matter of realizing that home was an illusion of coherence and safety based on the exclusion of specific histories of oppression and resistance, the repression of differences even within oneself. (196)

Largely defined by the sense of "not being home," the African American experience of home carries an intensified historical and traumatic weight, as it may be understood as a collective reference to the lost homeland of Africa and the search for a safe haven in the United States under the harsh conditions of slavery and the subsequent forms of institutionalized racial discrimination that continue to prevail in our day. This has been manifested on various levels: in the mass migrations of African Americans from the rural South to the industrial cities of the North, in religious metaphors and allegoriessuch as the exodus from the bondage in Egypt towards the promised land-coined by civil rights leaders, in literature, music, and other forms of art. Home has therefore become an ambiguous metaphor of security and freedom, and, simultaneously, of their absence. As Valerie Sweeney Prince suggests in Burnin' Down the House: Home in African American Literature (2005), "home is ubiquitous and nowhere at the same time" (2).

10 It is crucial to point out, however, that even under the brutal conditions of slavery, African Americans have been able to establish a sense of "being home." bell hooks emphasizes the political function of home in African American culture by defining it as a place of resistance in Yearning: Race, Gender, and Cultural Politics (1990):

Despite the brutal reality of racial apartheid, of domination, one's homeplace was the one site where one could freely confront the issue of humanization, where one could resist. Black women resisted by making homes where all black people could strive to be subjects, not objects, where we could be affirmed in our minds and hearts despite poverty, hardship, and deprivation, where we could restore to ourselves the dignity denied us on the outside in the public world. (42)

In hooks's view, home is characterized as an enclave within the system of institutional racism, a place of safety and freedom created and maintained primarily by women, who are responsible for building "a community of resistance" against white supremacy (Yearning 42). This argument runs parallel with Prince's suggestion that

[t]he act of place making, like all other constructions of identity, is necessarily communal. It operates in terms of inclusion and exclusion, and consequently precipitates the construction of binary oppositions like inside versus outside or "us" versus "them"-and these are debatable constructs. (69)

12 It becomes evident in the narrative that T.L. has never been able to experience home as a place of safety and resistance against the hostile world outside. Instead, he remembers it as a place of oppression, a confining structure, where he hardly experienced any sense of belonging or unity, and which prohibited him from making use of his intellectual capacity:

Daddy worked me to death and said, "Dat's life round here, boy." So I had to leave.

Hay fields, pea patches, cotton picking-I had had enough. I didn't ever acquire a nostalgic love for the place. (6)

This conflict between the idealized notion of home as a safe place and T.L.'s personal experience appears as a central issue in the novel. A major reason for T.L.'s sense of homelessness arises from his difficult relationship to Momma, who is not his biological 
mother. As is eventually revealed to T.L. himself only after his homecoming, he was actually born out of wedlock as a result of an affair between Daddy and Ms. Swinton, the school teacher (100). The fact that Momma is not T.L.'s biological mother is offered as an explanation for the difficult relationship between them, as she was forced to nurture and take care of the living, tangible token of her husband's infidelity (Twelve Gates to the City 32). Although Momma largely fulfils her role in maintaining home as a safe haven, her efforts tend to fail to extend to T.L., who has always felt excluded.

14 The ambiguity or unreliability of home is symptomatic of the traumatic memory of slavery that underlies the central antinomies of They Tell Me of a Home. The tension between the collective, traumatic sense of homelessness and rootlessness and, on the other hand, the ideal of home as a safe haven sets the stage for T.L.'s homecoming.

I...felt compelled to return to the place of my origin. Exactly why I didn't know, but for some reason I felt the need to go home. My heart, or my head, had begun to twist, to beg for familial clarity, in the last several years, and maybe, I hoped, Swamp Creek could help. Or maybe I dreamed of returning and finding a picturesque family into which I could safely place myself. (6)

T.L. comes back home in search of his familial and communal roots that he has, in effect, abandoned and rejected in his ten-year absence and complete lack of contact. He is driven by the desire to negotiate his sense of homelessness in order to arrive at what Katharina Schramm characterizes as "the comforting illusion of homecoming as the achievement of closure" (19). A significant part of this is his wish to reunite with the only member of his family with whom he has shared an affectionate relationship, that is, his little sister, Cynthia, usually referred to as Sister. It turns out, however, that she has died under obscure circumstances, and this substantially complicates T.L.'s homecoming. In addition to the personal endeavor to reestablish his cultural roots, T.L. is also motivated by a larger agenda, his idealistic impulse to change the world, to address what he regards as the main ideological problems of Swamp Creek, that is, social and political stagnation, incredulity towards education, patriarchy, and heteronormativity.

16 In some ways, T.L.'s return home is reminiscent of the diasporic mode of homecoming, a frequent theme in postcolonial literatures, in which, according to Avtar Brah, home often appears as "a mythic place of desire in the diasporic imagination" (192). In his exile, T.L. has not crossed any national borders or oceans between continents, but has, however, crossed a significant cultural boundary between his rural Southern community and the academic circles of New York. Despite his success in the academic context, the sense of displacement and dislocation that he experienced in his home and community in Arkansas has not vanished, and this has led him to travel back to his rural home. This complies with Schramm's notion of "the yearning for home as a coming to terms with one's own historical and political placement" (19). T.L. is haunted by the fear of abandoning his cultural heritage and roots, not necessarily in terms of the African American heritage in a larger sense, but primarily regarding the heritage of his more immediate and local cultural context at the level of family and community.

17 What makes T.L.'s homecoming particularly problematic is the fact that, ever since his childhood, he has never conformed to his community's sexism or heteronormativity. He has also resisted its commitment to physical labor, its skepticism about education, and what he perceives as a lack of communication and emotional expression. Many of these traits have been dominant in the discourses of 
hegemonic masculinity and patriarchy (see, for example, R. W. Connell 18, 55, and 128; bell hooks, We Real Cool: Black Men and Masculinity 2-12; and Sylvia Walby 19-21) and related to the patriarchal order in many agrarian cultures (see Deborah Simonton 57-69, 82). As a result of his failure to conform, T.L.'s relation to his community has always been characterized by a sense of estrangement and alienation.

18 These exclusionary ideologies are largely embodied in the novel by T.L.'s stern and strict father, who largely appears as T.L.'s binary opposite with his "patriarchy, sexism, and self-assumed superiority" (103). Interestingly, T.L.'s reading of his father's attitudes is infused with critical concepts that he has learned at the university in New York. After his homecoming, T.L. is immediately forced to realize that his ten-year absence has not altered their relationship:

I felt immobilized by his authoritative presence, and Daddy knew it. Since childhood, I was afraid of the sound of his voice. He would yell at me and cause sweat to break out all over my body, even in the winter. Whenever he was around, my equilibrium was shot, because I couldn't hold anything steady or speak without stuttering heavily. To one extent or another, he affected everyone in the family this way. (59-60)

Daddy's hegemonic position in the family is also expressed metaphorically in the text:

The old family car standing in the field, overgrown by grass and probably snakes, symbolized his divinely ordained position as head of the family and reminded me that, in whatever direction the family evolved, it was Daddy's life we were following. (168)

Highlighted in this passage is the politically stagnant and regressive quality of this patriarchy: the old car has been left in the field, unmoving, rusting, in effect, useless, but still maintaining its position as the iconic symbol of the status quo. In addition, the dominant power position of Daddy's patriarchal values is evident in the lack of communication between the members of the family: "Our family had always reverted to silence when speaking threatened to annihilate our comfort zones" (93).

21 The negative effects of patriarchy are not limited to the internal dynamics of the Tyson family; indeed, they become clearly visible in the novel in various instances, which all seem to possess a common denominator, that is, the reluctance of the community to accept difference. What underlies this is the illusion of cultural homogeneity and adherence to the cultural and social status quo that the people of Swamp Creek seek to uphold. One of the most conspicuous examples is articulated in T.L.'s reminiscence of how two women, Ms. Janey and Ms. Pauline, were excommunicated from the church because of their non-normative sexuality. The following passage exposes both the heteronormativity and the moral hypocrisy of the community:

Deacon Blue got up in church and said he had an announcement to make: "It hath been reported that some of our members is funny." Immediately everyone began to look at Ms. Janey and Ms. Pauline. "We all know God don't like dat. De Bible say homosexials is goin' to hell."

"Amen," people chimed.

"The Bible say fornicators are going, too," Ms. Janey said defensively and stood to her feet. "So if I'm goin', Blue, I'll definitely see you there!"

Everybody knew, back in the day, Deacon Blue had been a ladies' man, and Ms. Janey was making 
sure Deacon Blue understood God's judgment to affect every life. Her case didn't carry her far, though. The church voted unanimously to excommunicate them. (77) in a striking opposition to the apparently unsatisfying heterosexual relationship between Momma and Daddy and the patriarchal, heteronormative order of their family. The prejudice towards same-sex desire is evidently one important constituent of the ideological divide between T.L. and his community. This is where They Tell Me of a Home establishes a link to another contemporary Southern African American writer, Randall Kenan, and especially his novel A Visitation of Spirits (1989), which explores the issue of heteronormativity in the rural black South.

24 Another central issue underscored by the text is the way in which patriarchal ideology seeks to maintain a disproportionate power balance between genders. This becomes exemplified through Momma's subordinate position as she has to succumb to Daddy's will and take on the role as T.L.'s mother. Her life under patriarchal control has inevitably shaped her way of thinking:

Momma embraced all men as the same. If a woman was to have a man at all, and every woman needed a man, Momma said, she would simply have to tolerate his shit, and there was nothing she could do about it. I found it funny as a child that Daddy got all kinds of breaks while Momma was told to endure or get the hell out. (103)

Although Momma seems to wield some power within the domestic sphere, the point is that, within the patriarchal order, Daddy's will prevails and she has little choice other than to live with the consequences. This issue is further elaborated in the sequel, Twelve Gates to the City, in a discussion between Momma and T.L., where Momma explicitly articulates her position as a mother whom "yo' father treats like shit and still expects to cook his food and raise his bastard child. And I did it" (32).

26 Somewhat paradoxically, in the same discussion, she betrays her own adherence to patriarchal thinking by mocking T.L. for his indecision concerning his life, that is, for not behaving like a man should: "Grow up. Be a man. Decide where and how you gon' live, and stay there.....'m sayin' be man enough to make up yo' mind. Then do it” (32). Momma's situation and her words resonate with David Ikard's claim that "black patriarchy is partly sustained by unintentional black female complicity" and that

[t] he cultural affirmation of self-sacrifice compels black women to ignore suffering under patriarchy to support black men and preserve cultural solidarity, thereby rendering black women accomplices in their own subjugation. (5)

Through Momma the novel highlights the difficult position of black women between the responsibility to be committed to the family and tradition and, on the other hand, their own happiness and wellbeing, as responsibility and happiness do not necessarily coincide within patriarchal order. 
28 One of the central dividing lines between T.L. and his father is the stance towards physical labor:

Daddy's work came before everything else. Always. He believed, at the expense of everything, a man ought to work by the sweat of his brow, and Daddy upheld this conviction. He was obsessed with physical labor, afraid that one moment of rest would automatically prove him lazy, and Daddy would never allow anyone the opportunity to call him lazy. This was a principle he lived by and one he made all the rest of us live by, too. (They Tell Me of a Home 8)

T.L., conversely, abhors physical work, and he would rather devote his time to his greatest passion, that is, reading. As a result, from T.L.'s perspective, physical labor and the intellectual practice of reading have become binary opposites, the former representing conservative thinking and political stagnation, whereas the latter stands for social ascension, development, and change. It is crucial to note, however, that Daddy's "obsession" with work may be seen as driven by economic necessities and realities of life, that is, the position of post-slavery poverty that the family occupies under the conditions of late capitalism in the 1980s. Hard, physical labor becomes, therefore, a question of day-to-day survival, which also gives rise to the stance against reading and education as threatening the short-term view on the issue of livelihood and survival. This is spelled out by Daddy: "First thang he got to learn is how to work. All dat readin' ain't gon' put no food in his mouth. How a man s'pose' to make a livin', sittin' round on his ass wit' a book in his hands?" (8). The world as it appears to T.L.'s father is governed by the tough and relentless struggle for survival through hard physical work. The ongoing poverty in African American rural communities is a manifestation of the persistence of the effects of slavery and its aftermaths, to which hard physical work is both a practical and an ideological response.

30 Daddy's attitude assumes even more substantial weight when read in relation to historical developments. As Bernard W. Bell argues, the rise of the novel as a dominant cultural form was inherently related to the "social factors that mark the change of traditional, agrarian, oral cultures to modern, industrial, literate cultures" (73). Daddy's resistance to reading and literature therefore appears as emblematic of the resistance to larger social and cultural transformation and highlights the oppositions between the rural and the urban, the agrarian and the industrial, the oral and the literary. What complicates this position even further is the complex history of African American literacy. According to Henry Louis Gates, Jr., learning to read and write was a profoundly political act for black people during slavery because written culture was deemed as a precondition of humanity and, therefore, a potential step towards freedom from bondage ("Preface to Blackness: Text and Pretext" 147). Daddy's refusal to acknowledge the significance of literacy is one of the most conspicuous manifestations of the repression of history in the novel.

31 The Southern rural values and norms prevailing in Swamp Creek evidently involve questions of black identity in a larger, historical sense. The text emphatically proclaims that the feelings of inferiority and lack of self-worth evident in this black community are inextricably intertwined with conservative thinking and especially with the negative attitude towards education and reading. These issues find their clearest expression in the diaries of the school teacher of Swamp Creek, Ms. Swinton, which T.L., after finding she is his biological mother, acquires and reads:

I see the brilliance in the eyes of my students when they arrive early in the morning smelling like cow manure. The problem is that they don't see brilliance. That's why 
their homework doesn't get completed properly. They, and their parents, equate country with intellectual ineptitude. It's truly strange. The people in Swamp Creek function with the unspoken notion that "real intelligence" is an anomaly in southern, rural places. It's sad. And they teach their children likewise. (238)

According to Ms. Swinton, the most negative outcome of this distrust of learning is that generation after generation, the children of Swamp Creek have internalized the racialized stance of inferiority: “They're dying constantly. They think they're too black and too stupid to be of any value. Unfortunately, their folks inadvertently reinforce such notions" (156).

33 Although white racism and racial slavery are rather seldom mentioned in the text, it may be argued that the intellectual inertia of Swamp Creek results from the traumatic memory of slavery and its effects on African American identities. The fact that this collective memory has been largely repressed in the text may be read in terms of Fredric Jameson's idea of the political unconscious-as developed in his seminal work The Political Unconscious (1981) - evading direct expression, but present in its effects, as "an absent cause" (35). That is, the issues of racism and racial slavery have been pushed away from the consciousness of the people and from the surface of the narrative, but they play a crucial role via this collective political unconscious which surfaces in the guise of the abovementioned feelings of inferiority and intellectual ineptitude. This political unconscious may be detected in the text, for instance, at a metalevel, in the texts that are read within this novel, such as Ms. Swinton's diaries.

34 As T.L. returns home from the academic world of New York, where his thinking has become further distanced from the conservative agrarian ideological climate of Swamp Creek, a clash of values is imminent. This is articulated in the text allegorically through the Meetin' Tree, which assumes the position of a cultural icon that represents the values and practices of the black agrarian community. The tree is characterized in the text as "a great elder watching over a flock of children" (3). This allegorical reading of the Meetin' Tree may be pushed further by comparing two incidents in the novel. Firstly, T.L. reminisces how, in his childhood, the leaves of the tree would provide shelter from the rain, "like a big umbrella" (7), that is, functioning as a shield from outside influence, change, and growth represented by the rain in this dry, sun-scorched land. As he descends from the bus on the excruciatingly hot Arkansas afternoon of his homecoming, T.L. realizes that he is unable to rely on the tree in his search of shelter from the heat: “the Meetin' Tree didn't do me much good the Saturday I arrived, for even in the shade, I was still dripping with sweat" (7). The Meetin' Tree does not shelter the outsider from the heat that is characteristic of the summers in Swamp Creek. In addition, the hot air is completely stagnant despite T.L.'s attempt to cool himself by fanning the air with a notebook that contains drafts of his literary texts: "It did no good. Cool air had completely abandoned Swamp Creek" (7). The still, unmoving air is a metaphor for the conservative ideological and cultural climate of the community that refuses to be stirred by the movement of T.L.'s notebook, that is, an emblem of literature and education.

\section{Cultural Memory and Transcultural Spaces}

The clash of agrarian and academic values is represented on the aesthetic level in the novel through the modes of cultural expression to which they are primarily connected. 
This is where the tension between African based orality and Euro-American literacy becomes an important issue. The point of view represented by T.L., and also by Ms. Swinton, the school teacher who is his biological mother, emphasizes the importance of literature and reading; whereas the preferred mode of cultural expression in Swamp Creek is oral storytelling. According to Simon Featherstone, orality is often associated with illiteracy, and, therefore, as "a barrier to knowledge and progress, and a badge of cultural and economic backwardness" (185). Although T.L. initially seems to subscribe to this condescending, elitist stance, he eventually finds a new kind of appreciation for oral storytelling culture. This development highlights the redemptive possibilities of orality, that is, its emphasis on collectivity and capability to adapt to change. As Featherstone points out,

[o]ral communication of memory is, therefore, always socially based, constructed within a given moment of performance and, theoretically at least, open to response, debate and challenge. (187)

It may be argued that as a mode of cultural expression, oral storytelling opens up possibilities to deal with the problems of the community, but, as depicted in the novel, this has not been done profoundly enough. The black people of Swamp Creek have not, therefore, been able to relinquish the collective, internalized sense of racial inferiority and its intersectional collateral effects, such as sexism and heteronormativity. In other words, the capacity of orality to adapt to change has not been fully realized in Swamp Creek.

37 This is also where the issue of spatiality becomes central in the novel, as both modes of cultural expression (oral storytelling and writing) are connected to specific spaces within the contact zone created by T.L.'s homecoming. As far as reading and education are concerned, the novel discusses two specific sites: T.L.'s grandmother's house and Ms. Swinton's house. These spaces that clearly offer refuge from the surrounding ideological climate of Swamp Creek are crucial for T.L.'s future as a scholar of black studies, the former by providing him a chance to cultivate his talents and his passion for reading and the latter as an enclave of academic learning. Perhaps the most significant space in the novel is the Meetin' Tree, which assumes a crucial position, firstly, through its function as the space of the communal practice of oral storytelling and, secondly, as the primary scene where the ideological clash that becomes manifest through T.L.'s homecoming is negotiated.

38 In T.L.'s childhood, his grandmother's house used to be his refuge because she was one of the few people in Swamp Creek who diverged from the typical, hostile stance towards reading and encouraged him to use his talents:

When I started memorizing excerpts from black writers, Grandma said, "Amen! You comin' on home!" She loved my Dunbar recitations the best. His dialect poems made her laugh and cry simultaneously. After she gave me the first Dunbar book, she started getting me black books every Christmas and made me promise to read them and recite parts of them to her. I never failed....Grandma and I had created a sacred space there, sharing secrets and crying tears together. (28-29)

Grandma's house became a cultural and intellectual oasis for T.L., a place where he could cherish his devotion to reading and learning, an enclave surrounded by the conservative agrarian culture with little space for anything else than hard physical labor. In this cultural context, Grandma's house may be read as what Michel Foucault has referred to as a heterotopia, a real, existing place where the conventions and values 
of the community are represented and, simultaneously, contested ("Of Other Spaces" 24).

40 Another heterotopic space of reading and learning is Ms. Swinton's house, which reached well-nigh mythical proportions in T.L.'s mind during his adolescence: "It had once been my dream mansion" (146). Ms. Swinton has become the embodiment of learning in Swamp Creek and therefore T.L.'s primary role model. She used to keep her house and garden in an impeccable shape, displaying her impressive "ability to transfer her academic standards to the maintenance of a flower garden" (146). This proof that academic knowledge and practical competence are not mutually exclusive informs T.L.'s thinking and his eventual ideas of making use of his academic learning in order to help resolve the dilemmas of his community. When he returns home and goes to see Ms. Swinton, who is seriously ill, he is startled to see the deteriorating house and untended garden. Ms. Swinton's failing strength implies that the community might have a place and role for T.L. as her successor. This also implies the possible outcome of the cultural clash that caused by his homecoming. Inside the house, T.L. is amazed at all the books and the concomitant air of wisdom and knowledge:

I shoved the heavy mahogany door open and stepped into a literary gold mine. There were books everywhere. I found myself gawking around the room in awe, amazed to see books on the floor, on the sofa end tables, on shelves, and on the dining room table. I had never seen a million books in one room in my life. (147)

41 It is only later that T.L. finds out that Ms. Swinton is his biological mother, and this obviously puts everything in a new perspective. The books that he sees in the house, particularly by such iconic African American writers as James Baldwin, Zora Neale Hurston, Ralph Ellison, Ann Petry, Claude McKay, and Richard Wright, draw the entire tradition of African American literature into the texture of They Tell Me of a Home. Later in the narrative, as T.L. finally discovers the maternal link between Ms. Swinton and himself, the house assumes an even more important and personal meaning for him and, in Twelve Gates to the City, eventually becomes his home.

42 Both Ms. Swinton's house and Grandma's house play central roles in shaping T.L.'s consciousness and preparing him for what eventually becomes his calling, that is, his vocation as Ms. Swinton's successor as the school teacher of Swamp Creek. His indecision concerning Ms. Swinton's proposal to answer the call of his communal heritage and to pursue the rather underpaid career of educating the black community, "trying to lift the veil of inferiority" (The Tell Me of a Home 239), is established as one of the quintessential issues of the novel. Directly connected to this is the passage which depicts T.L.'s anticipatory fantasy of working as a teacher in Swamp Creek. It may be argued that the heterotopia of Ms. Swinton's house with all the literary learning and wisdom contained therein is inscribed and mediated to the textual level in her journals, which T.L. later reads in his old room. Reading the texts produced in the heterotopic space of Ms. Swinton's house gives rise to T.L.'s fantasy, the initial scene of which is the classroom, where T.L. teaches African American literature, culture, and history to the children. As he talks about slavery and the Underground Railroad, he takes the children to see an abandoned house which allegedly used to function as a hideaway place for fugitive slaves. Walking towards the house, T.L. detects a profound change in the children:

For the first time in most of their lives, the children walk with a confidence unshakable. I begin to cry as I watch them transform into the ancestors we were studying only moments before. They don't walk like poor country children 
anymore. They have been endowed with the power of self-love and selfbeauty....They have only one aim in mind, and that is to see if, in fact, the famous Underground Railroad came through Swamp Creek. I presume that if the children can actually see the dungeon, they will be convinced that their home is sacred, too. They need to verify that slaves ran to Swamp Creek to find safety. It will make their lives and the lives of all their people much more meaningful because then they can speak of themselves as significant contributors to American history. (243)

This scene is based on T.L.'s idea of using academic learning to contravene the internalized sense of inferiority inherited from the time of slavery and maintained by more recent forms of institutional racism. This endeavor is a direct continuation of Ms. Swinton's legacy and her conviction "that the power of education will transform the minds of the self-loathing" (240). This is also a manifestation of how the repressed memory of slavery functions as the political unconscious in the novel and becomes visible through its symptoms in this imaginary scene that T.L. constructs in his fantasy. What is at stake here may be read in accordance with Jameson's account of literary works as symbolic acts that produce imaginary solutions to real social contradictions (The Political Unconscious 79).

44 The central transcultural space, in my reading, is the Meetin' Tree, where cultural memory is manifested and negotiated. In addition to its role as a gathering place where the communal cultural practice of storytelling occurs on Friday nights, it evidently carries a lot of metaphorical significance in the context of African American history and literature. First of all, trees have become invested with the history of slavery and white racism through the practice of lynching, famously portrayed in the song "Strange Fruit," written by Abel Meeropol (under the pseudonym Lewis Allan), a Jewish American teacher and poet, and performed by Billie Holiday. A well-known literary example of this may be found in James Baldwin's gruesome piece of short fiction, "Going to Meet the Man." Toni Morrison's prize-winning novel Beloved (1987) with its depiction of the tree-shaped scar tissue in Sethe's back as a graphic representation of the memory of slavery and, simultaneously, as a sign of healing, is one of the best known references to trees in African American fiction. It may be argued that the Meetin' Tree assumes the function of a chronotope in They Tell Me of a Home. Mikhail Bakhtin defines the chronotope as

"time-space." A unit for studying texts according to the ratio and nature of the temporal and spatial categories represented....The chronotope is an optic for reading texts as $\mathrm{x}$-rays of the forces at work in the culture system from which they spring. (425-26)

It is my argument that the Meetin' Tree functions as a chronotope in which the spatiotemporal history of African America in condensed. It becomes a site of the memory of slavery and its aftermath in the guise of other manifestations of racism that penetrate the entire history of black America. Importantly, the tree does not remain a mere idle reflection of racial injustice, but also becomes a token of survival and resistance.

46 The historical symbolism of the Meetin' Tree enhances its role as a site of storytelling and of the cultural encounter between T.L. and Swamp Creek. The social significance of his special site may be understood in parallel with the communal importance of oral narratives, largely inherited from traditional West African cultures. According to Bernard W. Bell, in an anthropological sense, oral narratives as verbal art forms

have four principal functions. They transmit knowledge, value, and attitudes from one generation to another, enforce conformity to social norms, validate social 
institutions and religious rituals, and provide a psychological release from the restrictions of society. (73) gatherings at the Meetin' Tree. The ways in which the oral narratives performed at the Meetin' Tree produce communality and a sense of collective identity in Swamp Creek correspond to the idea of oral storytelling as a representation and vehicle of cultural memory. As Ansgar Nünning has pointed out, storytelling functions as a "medium of creating cultural coherence, of enhancing community feeling, and of forging collective identities" (172). This is in accordance with how, as James Fentress and Chris Wickham point out in Social Memory (1992), "social memory identifies a group, giving it a sense of its past and defining its aspirations for the future" (25).

48 The stories told at the Meetin' Tree gain additional importance vis-à-vis the cultural clash caused by T.L.'s homecoming. Content-wise, they appear in the novel as mainly humorous, sometimes ironic narratives of incidents in the lives of either the storytellers themselves or other members of the community. In terms of form, many of the conventions and recurring motifs of the traditional African American folklore are explicitly present. Particularly central examples of this include, firstly, the trope of telling lies. As Dwight N. Hopkins argues, discussing Zora Neale Hurston's Mules and Men (1935), "[1]ies are stories or tales delivered with verbal dexterity. They embody the art of living or how to be black in America" (286). At the Meetin' Tree, everyone in the audience knows that the story is too outrageous to believe, but the storyteller insists on every word being true. Reciprocity is another important formal feature in the storytelling situation. The audience participates actively by spurring the storyteller on, at times confirming what is being told and, at times, contradicting and accusing the speaker of lying. This process adopts the call-and-response pattern, which, as Gilroy points out, is a fundamental formal feature in the cultures of the black diaspora (78). These formal characteristics largely define the storytelling incidents as depicted in the They Tell Me of a Home.

49 Another important formal point is that the principal storytellers, Mr. Blue and Mr. Somebody, the most respected elders of the community, come across as trickster figures in their mastery over language, especially their use of black American English, and their ability to turn rather mundane events into hilarious stories and make the people who gather at the Meetin' Tree convulse with laughter. This also involves the use of the timbres of the voice and nonverbal gestures:

Mr. Somebody's antics alone induced chuckling. His eyes, mouth, and hands worked together, like a puppet's, in perfect gestural unity. Accompanied by a squeaky soprano voice far too high for most people's liking, his trembling arthritic hands shaped each word he spoke, forcing others not only to listen but to watch him. (265)

The reference to the old man's high, effeminate "squeaky soprano voice" is especially noteworthy, since trickster figures in many cultures tend to play with and transcend the boundaries of gender. A famous example of this is the trickster figure of Yoruba mythology, Esu-Elegbara, explicated by Henry Louis Gates, Jr. in The Signifying Monkey: A Theory of African-American Literary Criticism (1988) (see esp. 29). Interestingly, Mr. Somebody's androgynous character seems to suggest that the norms of gender and sexuality that prevail in the community are not inherently inscribed, but, instead, questioned in the storytelling tradition. The failure of the community to acknowledge this is one of the reasons for T.L.'s mobility and the eventual cultural clash. The exceptional, trickster-like quality of Mr. Somebody's character is further enhanced as 
he leaves the Meetin' Tree that night: "As he walked away, his body disappeared slowly into the abyss like a mystical being with spiritual powers of levitation" (276). As Featherstone argues, "the performance itself-its body and its moment-is necessarily part of the act of memory" (188). Read in this light, the oral storytelling in this novel functions as an instance of cultural memory, reaching beyond the memory of slavery all the way to African oral cultures.

51 The storytelling event is where the issues of spatiality are brought into focus. The Meetin' Tree becomes the most significant heterotopia in the novel and may be read in accordance with Foucault's definition, as a real, tangible space, where the phenomena of society can be at once represented and challenged ("Other Spaces" 12). In this special cultural space, the people of Swamp Creek provisionally transcend the categorizations that define them and their everyday lives in society:

The darkness erased the particulars of people's expressions and made all of us seem like spirits gathered at the tree. Who was cute and who wasn't and who had money and who didn't proved absolutely meaningless. We were all contributors unto a communal joy that was enough to sustain everyone.... As a child, I never noticed how wonderful it was to watch people abandon their daily roles and laugh out loud as they fashioned their own survival in a world prepared to kill them. This was one place and time where the power of white folks was of absolutely no consequence. (268)

In this passage, the heterotopic space undergoes a transformation. It becomes reconfigured as an imaginary space, as an allegory of a new kind of communality, a vision of a world where the significance of social categorization is radically diminished. In Fredric Jameson's terminology, this space becomes a utopian enclave, an imaginary space where "new wish images of the social can be elaborated and experimented on" (Archaeologies of the Future 9). This reading is further supported by the following quotation:

The old, the young, the unsure, the desperate, the loud, the soft-spoken all put in their two cents as we constructed, if only temporarily, a world where everyone was free. The differences that disallow unity in America never interrupted our space as we listened to story after story, regardless of who was telling it. (They Tell Me of a Home 268)

This dissolving of identity categories at the Meetin' Tree is accomplished through the collective act of storytelling, which functions as a way of negotiating the traumatic cultural memory of slavery and racism in the United States. The empowering communal functions of storytelling are clearly present in these passages in providing people with a sense of unity and relief from the burdens of everyday life.

54The reading proposed above, however, introduces some complicated issues as far as the political functions of oral storytelling are depicted in the novel. The stories told at the Meetin' Tree rarely deal with the larger problems that the community is facing. This is an important point, because it may be understood as a symptom of the repressed political unconscious of the novel, that is, the traumatic memory of slavery and its ongoing effects on the community. While the fundamental social functions of storytelling are implied in the narrative, what comes across most explicitly is the aspect of psychological release from societal restrictions:

[P]eople relinquished their inhibitions freely and shared intimacies otherwise taboo. Folks who were solemn all week laughed easily once they arrived at the tree, for somehow the space released Swamp Creek residents from the confinements and constructs of the world, which told them they were not supposed to have joy. (259) 
55 harsh realities of the poverty and tough physical labor that largely define their everyday lives. The primary function of storytelling and its heterotopic space at the Meetin' Tree, as suggested in the text, seems to be to provide a survival strategy to help the people to cope with the hardship of their lives, but it does not really lead to any fundamental change. In a political reading, this practice comes dangerously close to politically idle escapism. Although the ecstatic storytelling occasions at the Meetin' Tree undeniably serve important beneficial social functions within the black community, they tend to fall short of addressing the internal problems of the black rural community and of the larger American ideological and political status quo, particularly the racist, sexist, and heteronormative tendencies and their practical effects in society. This may be understood as a result of the fact that the huge, fundamental dilemmas that underlie the more clearly manifest problems within the black community, that is, the issues of white supremacy and the internalized black inferiority, tend to be repressed, rather than polemically addressed. This reading also complies with the ideological climate of Swamp Creek that seems to resist change: "People there loved words, but they weren't interested in changing their ideas" (124).

56 The stories told at the Meetin' Tree are simultaneously negotiations and instances of repression, of revelation and disillusion. As Alisa K. Braithwaite argues,

the stories we tell each other and ourselves help us to negotiate our environment, particularly when much of our environment is out of our control. These stories also help us to understand (and sometimes prevent us from understanding) ourselves. Our cultures are produced through collections of narratives that support and refute each other and that evolve as we continue to collect more information. (83)

This applies to the storytelling practice of Swamp Creek. The oral narratives allow the people a much needed break from the toil of daily life and work, but do not directly challenge the social status quo. They function as a means of survival and communality, but fail to question the exclusionary and oppressive ideologies that prevent the development of the community and seriously complicate the lives of those who do not conform to its norms. In effect, they operate at the intersection of the preservation of the continuity of tradition and the reactionary and oppressive identity politics of the community.

58 This is where T.L.'s role and the process of transculturation become crucial. His presence at the Meetin' Tree interrupts the traditional merrymaking and the carnivalesque air of the gathering and reconfigures this cultural space and its sociopolitical functions. He produces a counternarrative that partly refutes and partly aligns with the cultural practice of storytelling at the Meetin' Tree. He supports the ways in which oral narratives transmit cultural memory and produce communality and collective identity, but, simultaneously, he uses the oral tradition to confront sexism and heteronormativity, influenced by his academic studies and such African American writers as James Baldwin and Langston Hughes. As a consequence, he becomes a transcultural mediator between the storytelling tradition of the black rural community and the literary cultures that he has studied at the university.

59 On the Friday night when he participates in the storytelling gathering after his tenyear hiatus, T.L. is more than ever impressed by the event and its empowering communality: "We are already in the land of milk and honey because we're black and together" (268). His own contribution to the gathering reaches its peak as his remarks 
inspire Mr. Blue and Mr. Somebody to discuss what they perceive as the negative effects of education:

"If education don' bring us closer together as a people, then it ain't no good. Dat's brainwashin' and white folks is benefittin' as our communities is fallin' apart. You college-degree children can go to white schools and live in white neighborhoods, and y'all thankin' y'all done progressed. Shit! You done gone straight backward! You know why? 'Cause you love his shit more than you love yo'self." (269) community has concerning education: that the educated leave the community and reject its traditions and heritage permanently in hopes of climbing the social ladder. Therefore, individualistic social ascension and respect for one's communal and cultural heritage become established as opposites in the text.

61 To an extent, this may be understood in terms of the gap between older and younger generations, exemplified by the fundamental ideological disagreements between T.L. and his father. In fact, the former comes across as a Du Boisian figure, a representative of the Talented Tenth, who advocates radical social ascension and the power of education, whereas T.L.'s father could be read in accordance with Booker T. Washington's more conservative views. The text, however, suggests that T.L.'s father and a majority of the black community hold and perpetuate a strictly negative attitude towards education, which stands in opposition to Washington's pro-education agenda. The generational gap cannot, in the end, explain the ideological differences, since most of the younger generation seems to have adopted the same hostile principles of the older generation towards education, as suggested in Ms. Swinton's diaries discussed above.

62 The same issues are also represented at some length in Twelve Gates to the City, in a similar storytelling incident, where the outrageous, humorous stories momentarily give way to more serious reflection on the state of the community and the related issues of cultural heritage and education:

“That's why black folks can't keep no young people in our communities no more. We send 'em away. We tell 'em to go find a life when we shoulda been teachin' 'em the beauty o' the life we had!" (106)

This balancing act represented in both novels is that between tradition and change. The problem is that for this community tradition and change seem to be mutually exclusive: tradition translates into stagnation and political passivity, while change is believed to lead inevitably to a complete rejection of tradition. T.L. understands this fear of change and rejection, but counters it through his own example, returning home and participating in the storytelling event. Mr. Blue acknowledges this:

"Learnin' is a good thang when it's done right, and black people could use a whole lot of it. Like take dis boy hyeah for 'xample. ... He done gone off to school and got a whole buncha degrees, but he can still come home and laugh and talk wit' de rest of us wit'out thankin' he's too good to swat mosquitoes and listen to old nigga stories." (269)

This is where T.L.'s role as a transcultural mediator between the conflicting cultures becomes clearly visible.

65 When he is asked to present what he has learned concerning African American history and culture, T.L. raises the issue of black slave owners, which the people at the Meetin' Tree initially write off as impossible. By elaborating further on the issue and backing it up by referring to academic research, T.L. eventually manages to convince 
the people. This results in Mr. Blue's proclamation: “'See? Now dat's what education s'pose to do. You s'pose to learn something dat make you think"' (271). At this moment and in this space, the old storytelling tradition of Swamp Creek and literary learning, represented by T.L., clash in a productive way, which creates an enhanced sense of mutual respect and understanding. T.L. finds a renewed appreciation for the cultural tradition of his home community, and it is exactly this that enables him to become the transcultural mediator between storytelling and reading, between the agrarian culture of Swamp Creek and the academic world. As a consequence, the seeds are sown in the community for a more positive kind of attitude towards learning and change. This is the moment when the position of the Meetin' Tree as a utopian enclave is confirmed, highlighting the possibility of erasing the inherited, internalized sense of intellectual ineptitude and inferiority, carried by the cultural memory of slavery, without rejecting the valuable black cultural heritage.

66 There is also another level on which T.L. assumes the position as an embodiment of transculturation. In addition to his academic pursuits, he is an aspiring creative writer and poet whose work is based on the fusion of literary conventions and the tradition of African American storytelling, that is, the stories told at the Meetin' Tree: "The stories people told at the Meetin' Tree became my text and gave me foundation for understanding the art of good literature" (121). This transcultural fusion of oral and literary traditions is a significant characteristic of African American literature, and its presence at a metalevel of the narrative, in the form of T.L.'s literary ambitions, adds to the aesthetic dimensions of transculturation in the novel, where oral and literary narratives are intertwined. Interestingly, these ambitions also clearly contain a didactic and political agenda:

Nothing intrigued me more than to tell stories of how black people survived and how we created laughter in the eye of the storm. I wanted my words to heal hearts, incite joy, evoke tears, and initiate change....I wanted such power in order to get on the inside of people and help them fix things. My dream was that, one day, one of my poems or short stories would make people cry or love themselves into their own liberty. (121)

67 Following the example of African American literary tradition, T.L.'s literary efforts seek to combine aspects of both African American oral storytelling and literary expression and thereby to facilitate social and political change. In the context of the cultural clash represented in the novel, this strategy would avoid the problems of political passivity and intellectual ineptitude that haunt Swamp Creek without rejecting the immeasurable value of African American cultural traditions. This is how content and form function in conjunction to enhance the transcultural processes in the novel.

\section{Conclusion}

68 Although They Tell Me of a Home focuses on what could be thought of as an intracultural context, in the sense that the protagonist, T.L., returns to his all-black, southern, agrarian community, the novel is marked by a process of transculturation that occurs at the intersection of academic values and the traditions of the Southern black community of Swamp Creek. This results in the reassessment of the initial conflict between the seemingly backward, conservative cultural heritage of Swamp Creek and the ideals of education and academic literary learning. In many ways, T.L. becomes the personification of this transculturation process, as he functions as a mediator, as a 
bridge between worlds and across boundaries. As Ms. Swinton, the legendary school teacher of Swamp Creek and his biological mother, names T.L. as her successor, his role is further enhanced, although his eventual decision to accept the vocation is merely implied at the end of the novel. He becomes the potential savior figure who is supposed to carry the burden of erasing the racialized sense of inferiority inherited from the history of slavery and racism, or, to paraphrase Pratt's account of the contact zone, the devastating conditions of the aftermath of colonialism and slavery (4), in which the people of Swamp Creek struggle to live their lives.

69 In my reading of They Tell Me of a Home, transculturation is understood as a reciprocal process. The novel seems to point out that regarding oral storytelling and reading as mutually exclusive binary opposites, leads to either communal political stagnation or individualistic elitism. By the end of the novel, however, they appear as parts of the same "cultural ensemble that cannot be apprehended through the manichean logic of binary coding," to borrow Gilroy's words (198). The narrative trajectory of the novel works to combine both of these aesthetic modes into a new synthesis. What emerges from the text is an idea of education which would not endorse a colonization of the black cultural heritage by academic ideals, but would, rather, celebrate the strengths and negotiate the problems of both. In effect, both of these seemingly contrary traditions would be divested of their exclusionary and oppressive tendencies. This becomes especially clear after the storytelling event, when T.L. finally understands why he decided to come home in the first place:

I left the tree, however, realizing my coming home was because, in all my academic pursuits, I had missed the most critical lesson any student can learn-that transforming the world begins with love of one's own people. (277)

70 In the end, T.L. has acquired a new and enhanced appreciation of his cultural heritage, especially the ability of the people to "sing their troubles away" (6) and also managed to start the process of convincing the people of Swamp Creek that education does not necessarily lead to the rejection of one's cultural and communal roots. This is where transculturation in its characteristically utopian guise assumes the center stage in the narrative. By gaining a deeper understanding of the strength of the cultural heritage of his community, T.L. becomes equipped to help it survive and develop instead of remaining in a state of stagnation and withering. He is, in the end, firmly rooted in the traditions of his home community, while remaining critical of its shortcomings and ideological distortions. As a consequence, he becomes the messenger of hope for the future of the black community of Swamp Creek, a site where the threats and their potential remedies are embodied. In other words, T.L. evolves into a cultural mediator, a transcultural personification and prospective resolution of the conflicting political and cultural impulses in the novel. He stands, in terms of Gilroy's thinking, at the intersection of "two great cultural assemblages": African and Western (1). He may, therefore, be regarded as an embodiment and personification of the black Atlantic; a site where these conflicting cultural traditions and their respective modes of expression meet and intertwine. 


\section{BIBLIOGRAPHY}

Bakhtin, M. M. The Dialogic Imagination. Ed. Michael Holquist. Trans. Caryl Emerson and Michael Holquist. Austin: U of Texas P, 1981. Print.

Baldwin, James. “Going to Meet the Man.” Going to Meet the Man. 1965. London: Penguin, 1991. 229-52. Print.

Bell, Bernard W. The Contemporary African American Novel: Its Folk Roots and Modern Literary Branches. Amherst: U of Massachusetts P, 2004. Print.

Black, Daniel. They Tell Me of a Home. New York: St. Martin's Griffin, 2005.

---. Twelve Gates to the City. New York: St. Martin's Griffin, 2011. Print.

Brah, Avtar. Cartographies of Diaspora: Contesting Identities. London: Routledge, 1998. Print. Braithwaite, Alisa K. "Connecting to a Future Community." The Black Imagination: Science Fiction, Futurism and the Speculative. Ed. Sandra Jackson and Julie E. Moody-Freeman. New York: Peter Lang, 2011. 81-99. Print.

Canzler, Weert, Vincent Kaufmann, and Sven Kesselring. "Tracing Mobilities - An Introduction." Tracing Mobilities: Towards a Cosmopolitan Perspective. Ed. Weert Canzler, Vincent Kaufmann, and Sven Kesselring. Aldershot: Ashgate, 2008. 1-10. Print.

Connell, R. W. Masculinities. Cambridge: Polity, 1995. Print.

Du Bois, W. E. B. The Souls of Black Folk. 1903. New York: Dover Publications, 1994. Print.

Eyerman, Ron. "Cultural Trauma: Slavery and the Formation of African American Identity." Cultural Trauma and Collective Identity. Jeffrey C. Alexander et al. Berkeley: U of California P, 2004. 60-111. Print.

Featherstone, Simon. Postcolonial Cultures. Edinburgh: Edinburgh UP, 2005. Print.

Fentress, James, and Chris Wickham. Social Memory. Oxford: Blackwell, 1992. Print.

Foucault, Michel. “Of Other Spaces.” Diacritics 16.1 (1986): 22-27. Print.

---. “Other Spaces: The Principles of Heterotopia." Lotus International 48-49 (1985-86): 9-17. Print. Gates, Henry Louis, Jr. "Preface to Blackness: Text and Pretext." 1979. African American Literary Theory: A Reader. Ed. Winston Napier. New York: New York UP, 2000. 147-64. Print.

---. The Signifying Monkey: A Theory of African-American Literary Criticism. 1988. New York: Oxford UP, 1989. Print.

Gilroy, Paul. The Black Atlantic: Modernity and Double Consciousness. London: Verso, 1993. Print. hooks, bell. Yearning: Race, Gender, and Cultural Politics. Boston: South End, 1990. Print.

---. We Real Cool: Black Men and Masculinity. New York: Routledge, 2004. Print.

Holiday, Billie. "Strange Fruit.” 1939. The Very Best Of Billie Holiday. By Lewis Allan. Verve, 1999. CD.

Hopkins, Dwight N. "Lies Above Suspicion: Being Human in Black Folk Tales.” Deeper Shades of Purple: Womanism in Religion and Society. Ed. Stacey M. Floyd-Thomas. New York: New York UP, 2006. 282-90. Print. 
Hurston, Zora Neale. Mules and Men. 1935. New York: Harper Perennial, 2008. Print.

Ikard, David. Breaking the Silence: Toward a Black Male Feminist Criticism. Baton Rouge: Louisiana State UP, 2007. Print.

Jameson, Fredric. Archaeologies of the Future: The Desire Called Utopia and Other Science Fictions. London: Verso, 2005. Print.

---. The Political Unconscious: Narrative as a Socially Symbolic Act. 1981. New York: Cornell UP, 1982. Print.

Kenan, Randall. A Visitation of Spirits. 1989. New York: Doubleday, 1990. Print.

Martin, Biddy, and Chandra Talpade Mohanty. "Feminist Politics: What's Home Got to Do with It?" Feminist Studies/Critical Studies. Ed. Teresa de Lauretis. Houndmills: Macmillan, 1986. 191-212. Print.

Morrison, Toni. Beloved. 1987. London: Vintage, 1997. Print.

Nünning, Ansgar. "Narrativist Approaches and Narratological Concepts for the Study of Culture." Travelling Concepts for the Study of Culture. Ed. Birgit Neumann and Ansgar Nünning. Berlin: De Gruyter, 2012. 145-83. Print.

Pratt, Mary Louise. Imperial Eyes: Travel Writing and Transculturation. London: New York, 1992. Print.

Prince, Valerie Sweeney. Burnin' Down the House: Home in African American Literature. New York: Columbia UP, 2005. Print.

Schramm, Katharina. African Homecoming: Pan-African Ideology and Contested Heritage. Walnut Creek: Left Coast Press, 2010. Print.

Schulze-Engler, Frank. "Transcultural Modernities and Anglophone African Literature." Transcultural Modernities: Narrating Africa in Europe. Ed. Elisabeth Bakers, Sissy Helff, and Daniela Merolla. Spec. issue of Matatu 36 (2009): 87-101. Print.

Simonton, Deborah. A History of European Women's Work: 1700 to the Present. London: Routledge, 1998. Print.

Walby, Sylvia. Theorizing Patriarchy. Oxford: Blackwell, 1990. Print.

Washington, Booker T. Up from Slavery. 1901. Ed. William L. Andrews. New York: Norton, 1996. Print.

\section{ABSTRACTS}

This article offers a transcultural reading of the issues of cultural trauma and mobility in Daniel Black's novel They Tell Me of a Home (2005). The protagonist, T.L., returns to his agrarian home community, Swamp Creek, in Arkansas, after a ten-year absence in which he received a PhD in black studies in New York. His homecoming foregrounds the cultural clash between the patriarchal black community and the elitist academic world that T.L. represents. This is articulated in the novel at the aesthetic level as the tension between the oral storytelling tradition of the black community and the literary expression favored by T.L. The opposite sides of the cultural clash and their respective modes of cultural production are understood as ways of dealing with the cultural memory of slavery and its aftermaths. The Meetin' Tree, the site of storytelling in Swamp Creek, becomes a transcultural space where these issues are negotiated. T.L. eventually adopts a newfound appreciation for his cultural roots and also initiates a change 
in the negative attitudes of the community towards education and reading. He thereby becomes a transcultural mediator between these conflicting cultures, aiming to stress and combine their strengths and to negotiate their weaknesses.

INDEX

Keywords: African American fiction, cultural memory, mobility, spatiality, transculturation

\section{AUTHOR}

PEKKA KILPELÄINEN

University of Eastern Finland 